\title{
THE EFFECT OF AUDIT OPINION, KAP SIZE \& FINANCIAL DISTRESS ON AUDITOR SWITCHING
}

\author{
Desi Natalia, Listiya Ike Purnomo \\ Universitas Pamulang, Tangerang Selatan, Indonesia \\ listiyaike81@gmail.com
}

\begin{abstract}
This research is examining factors that affect auditor switching. Those factors are audit opinion, KAP size and financial distress. Population of this research are maufacturing companies which are listed in Indonesian Stock Exchange in the years 2013-2017. Total sample in this research are 55 companies using purposive sampling method. The data used is secondary data obtained from the company's financial statements and independent auditor's report published in the website www.idx.co.id. Data analys by using logistic regression analysis method. Result of this research is Audit Opinion and CPA firm size have significant effect with auditor switching. Meanwhile, financial distress does not have signifiicant effect with auditor switching.
\end{abstract}

Keywords : Audit Opinion; CPA Firm Size; Financial Distress; Auditor Switching.

\section{INTRODUCTION}

A company's financial statements are a source of information regarding operational activities and financial position. Therefore, a financial statement must show the actual state of the company to be used as material for consideration in making decision. Financial statements must be able to present facts about the company's activities and is the basis for decision making both internal and external parties. (Januarti, 2011).

Several parties who have an important role in financial statements, namely company owners, creditors, financial institutions, investors, government and the general public. With the parties having an interest in the financial statements, must be presented in a relevant, accurate, complete and reasonable manner so that the needs of each party can be met. The auditor must examine financial statements objectively and independently of the information that will be presented in the financial statements to improve the reliability. The reliability is needed by stakeholders because they affect decision making. (Pasaribu, 2017).

When the auditor carries out auditing duties, absolute independence must be present in the auditor because it requires him to attest to the fairness of his client's financial statements. Naturally, users of financial statements, regulators, and other parties always question whether the auditor can be independent in carrying out their duties. Doubts about independence are growing because public accounting firms have been given the 
freedom to provide non-audit services to the clients they audit. The provision of non-audit services adds to the amount of financial dependencies of the accounting firm to its clients.

The audit engagement period is one way to prevent the auditor from getting too close to the client, thereby disrupting the auditor's independence. Implementation of auditor turnover (KAP) must be able to increase auditor independence both in fact, attitude and appearance (Giri, 2010). Auditor switching is the change of auditor and KAP made by the company. There are voluntary switching auditors and mandatory switching auditors. Benefit of auditor switching or KAP is to improve the audit competitive environment due to the increased need for audit services in companies that are public or nonpublic, and reduce audit costs. The company has many choices of accounting firms and auditors to choose according to the company's needs and company needs, as well as the choice of audit fees (looking for

\section{LITERATURE REVIEW}

\subsection{Agency Theory}

Replacement management generally applies a new accounting method so that the new management hopes to be more able to cooperate with the substitute KAP and hopes to get an opinion in accordance with the wishes of management so as to encourage management in the GMS to replace the KAP (Sinarwati, 2010). An agency relationship arises when one or more principles make an engagement with another person as accounting firms with cheaper audit fees). (Chi et al, 2009 in Faradilla \& Yahya, 2016).

Cases involving changes in public accounting firms that affect manufacturing companies and differences of opinion about what factors actually affect the change of auditors in manufacturing companies in Indonesia are interesting to study. Another motivation in conducting this research is that if a company replaces its KAP that has been auditing for five years based on the Decree of the Minister of Finance, this will not raise questions because it is mandatory. So what needs to be investigated is if the change of auditors is voluntary. The formulation of the problem are:

a. Does Audit Opinion affect Auditor Switching for manufacturing companies in Indonesia?

b. Does KAP size affect Auditor Switching for manufacturing companies in Indonesia?

c. Does Financial Distress affect Auditor Switching in manufacturing companies in Indonesia?

an agent to perform a service. Conflicts of interest between owners and management occur because of the possibility that agents do not always act in accordance with the interests of the principal, thereby triggering agency costs. In agency theory, the independent auditor acts as an intermediary between agents and principles with different interests.

\subsection{Signaling Theory}

The positive thing about signal theory is that companies that provide 
good information will distinguish them from companies that do not have "good news" by informing the market of their situation, signals about good future performance provided by companies, whose poor past performance will not trusted by the market (Wolk and Tearney, 2001 in 2018).

\subsection{Auditor Switching}

Based on theoretical evidence, the existence of auditor rotation results in a shorter audit engagement period and the company will move the auditor (Nasser et al., 2006 in Haruman, 2016). It arises because of factors that can originate from client factors or auditor factors. If the company performs auditor switching voluntarily, this is because the previous KAP acted conservatively and was not in line with the interests of the company's management, so the company did auditor switching, the main focus was on the client. If there is a mandatory change of auditors, what happens is that the auditor is forced to separate by applicable regulations and the main focus is on the auditor. (Mardiyah, 2002 in Utami, 2013).

\subsection{Audit Opinion}

Auditor opinion is about the fairness of the presentation of the company's financial statements where the auditor is conducting the audit. The Indonesian Institute of Accountants (2012) states that: "The audit report must contain a statement of opinion regarding the financial statements as a whole if the overall opinion cannot be given, then the reasons must be stated".

\subsection{KAP size}

KAP size can be said to be large if the KAP is affiliated with the Big Four, has branches and clients of large companies and has a professional staff of more than 25 people. Whereas the KAP size is said to be small if it is not affiliated with the Big Four, does not have a branch office and its clients are small companies and the number of professionals is less than 25 people (Arens et al., 2008: 33) in Utami (2013).

\subsection{Financial Distress}

Companies that are threatened with bankruptcy, the financial position may have an important impact on the decision to defend the firm. The condition of client companies that are threatened with bankruptcy tends to improve the auditor's subjectivity and caution evaluation. Under these conditions a company will tend to change auditors.

\subsection{Research Hypothesis}

The hypotheses in this study are:

H1: Audit Opinion has an effect on auditor switching.

$\mathrm{H} 2$ : KAP size is suspected to have a effect on auditor switching.

H3: Financial Distress has an effect on auditor switching

\section{RESEARCH METHOD}

Type of research is quantitative research because the data used in the form of numbers and analyzed with statistical assistance. 


\subsection{Data Collection Techniques}

Data collection techniques used documentation techniques, namely the use of data derived from existing documents. This is done by tracing and recording information needed in the form of audited financial statements of sample companies. The instrument in this study is secondary data collection, namely audited financial statements of manufacturing companies available on the official site of the Indonesia Stock Exchange or www.idx.co. id.

\subsection{Operational Definitions of Variables}

Auditor switching is the replacement of KAP by clients that is done outside the rules of public accounting services set by the Indonesian government. This variable is a dummy variable. If the client company during the research period, from 2013-2017, conducted auditor switching, then a value of 1 . Whereas, if the client company did not conduct auditor switching within that time period, then a value of 0 . (Lesmana \& Kurnia, 2016).

Audit opinions are grouped into 2 groups, unqualified opinion groups, and opinion groups other than fair without exception (fair without exception in explanatory language, fair with exceptions, unreasonable and disclaimer). The audit opinion variable is proxied by the dummy variable where the company that receives a fair opinion without exception is given a value of 1 and the company that receives an opinion other than fair without exception is given a value of 0 . (Haruman, 2016).

The size of the KAP is the size of the KAP that is divided into two groups, namely KAP affiliated with Big 4 and KAP that are not affiliated with Big 4. Measurement of KAP size variables uses dummy variables. If KAP falls under the category of The Big 4, it is coded 1, if it is not coded 0 (Sinarwati, 2010).

Financial distress is a condition of a company that is in a state of financial difficulties. Financial distress is proxied by use a DER (debt to equity ratio) from manufacturing companies which can be stated in the following formula:

DER = Total Debt / Total Equity

\subsection{Sample Collection Techniques}

The sample collection method used purposive sampling is a sample selection method based on certain criteria to obtain a sample that is representative of the population. Determination of sample criteria is needed to avoid the occurrence of mispesification in the determination of research samples which will further affect the analysis. The sample requirements used in this study are samples that present complete financial information with specific criteria as follows:

1. The manufacturing sector that publish annual financial reports between 2013-2017 which are listed on the Indonesia Stock Exchange.

2. The financial statements have been audited by a public accounting firm.

3. The financial statements are presented in rupiah.

4. Samples that present complete information needed for research. 


\subsection{Data Analysis Techniques}

Logistic regression analysis method used because it has one dependent variable which is non metric (nominal) and has more than one independent variable. This analysis is used to determine the effect of several independent variables $(\mathrm{X})$ on the dependent variable (Y). The regression model in this study is as follows:

$\mathrm{Y}=\alpha+\beta 1 . \mathrm{AO}+\beta 2 . \mathrm{KS}+\beta 3 . \mathrm{FD}+\mathrm{e}$

\section{RESULTS AND DISCUSSION}

\subsection{Result}

\section{Multicollinearity test}

Based on multicollinearity test results on table 1, the tolerance value of the Audit Opinion (OA) variable is 0.896 , KAP Size (KAP) is 0.908, and Financial Distress (FD) is 0.978. All three variables in this study have tolerance values above 0.10 which indicates there is no correlation between independent variables. The
Information :

$\mathrm{Y}=$ Auditor Switching

$\alpha=$ Constant

$\beta 1, \quad \beta 2, \quad \beta 3=$ Coefficient of independent variable regression

$\mathrm{AO}=$ Audit Opinion

$\mathrm{KS}=\mathrm{KAP}$ size

$\mathrm{FD}=$ Financial Distress

$\mathrm{e}=$ Residual Error

Table 1: Multicollinearity Test

Coefficients $^{\mathrm{a}}$

\begin{tabular}{|c|c|c|c|c|c|c|c|}
\hline \multirow[b]{2}{*}{ Model } & \multicolumn{2}{|c|}{ Unstandardized } & \multirow{2}{*}{\begin{tabular}{|c|} 
Standardized \\
Beta \\
\end{tabular}} & \multirow[b]{2}{*}{$\mathrm{T}$} & \multirow[b]{2}{*}{ Sig. } & \multicolumn{2}{|c|}{ Collinearity } \\
\hline & B & Std. & & & & Tolerance & VIF \\
\hline (Constant & .624 & .052 & & 11.963 & .000 & & \\
\hline OA & - & .053 & -.308 & -5.523 & .000 & .896 & 1.11 \\
\hline KAP & - & .049 & -.307 & -5.540 & .000 & .908 & 1.10 \\
\hline FD & - & .025 & -.106 & -1.982 & .048 & 978 & 1.02 \\
\hline
\end{tabular}

a. Dependent Variable: SWITCH

Source : output SPSS

Test the Feasibility of the Regression Model

Tabel 2: Hosmer and Lemeshow Test

\begin{tabular}{|r|r|r|r|}
\hline Step & Chi-square & df & \multicolumn{1}{c|}{ Sig. } \\
\hline 1 & 13.576 & & 8 \\
\hline
\end{tabular}

Source : output SPSS

same results were also shown by the VIF values of the four independent variables which showed a number below 10, where the VIF value of Audit Opinion (OA) was 1,116, the KAP Size (KAP) was 1,102 , and the Financial Distress (FD) was 1,022. From these results, it can be concluded that the regression model is free of multicollinearity between variables. 
Based on Table 2 shows the results of hosmer and lemeshow testing, with the probability of significance showing the number 0.094. The significance value obtained is greater than 0.05 so $\mathrm{H} 0$ is accepted. This means that the regression model is feasible to be used in further analysis, because there is no real difference between the clarification predicted and the observed classification. In other words, the regression model is able to predict the value of its observations.

\section{Assessing the Overall Model}

\begin{tabular}{|c|c|c|}
\hline \multicolumn{3}{|c|}{$\begin{array}{l}\text { Tabel 3: Likelihood L Block Nol } \\
\text { Iteration History }\end{array}$} \\
\hline \multirow[b]{2}{*}{ Iteration } & $-2 \log$ & Coefficients \\
\hline & likelihood & Constant \\
\hline \multirow{4}{*}{\begin{tabular}{l|l} 
Step \\
0
\end{tabular}} & 312.456 & -982 \\
\hline & 312.001 & -1.073 \\
\hline & 312.001 & -1.075 \\
\hline & 312.001 & -1.075 \\
\hline \multicolumn{3}{|c|}{ a. Constant is included in the model. } \\
\hline \multicolumn{3}{|c|}{ b. Initial -2 Log Likelihood: 312.001} \\
\hline
\end{tabular}

Tabel 4: Likelihood L Block Pertama

\begin{tabular}{|l|l|l|l|l|l|}
\hline \multirow{2}{*}{$\begin{array}{l}\text { Iter } \\
\text { atio }\end{array}$} & -2 & Log & \multicolumn{4}{|c|}{ Coefficients } \\
\cline { 2 - 6 } & & Constant & OA & KAP & FD \\
\hline 1 & 251.52 & .497 & -1.163 & -1.077 & -.197 \\
\hline 2 & 240.662 & .728 & -1.480 & -1.700 & -.294 \\
\hline 3 & 239.815 & .789 & -1.561 & -1.965 & -.319 \\
\hline 4 & 239.804 & .794 & -1.567 & -2.001 & -.320 \\
\hline 5 & 239.804 & .794 & -1.567 & -2.002 & -.320 \\
\hline \\
a. Method: Enter \\
b. Constant is included in the model. \\
\hline \multicolumn{7}{|l}{ c. Initial -2 Log Likelihood: 312.001 } \\
\hline
\end{tabular}

From table 3 and table 4 it can be seen that the value of LogLikelihood in block numer 0 is 312,001 while in table 4.5 . block number 1 is 239,804 . a decrease in value of -2LL amounted to $72,197$. Decreasing the value of $2 \mathrm{~L}$ can be interpreted that the addition of independent variables into the model shows that the regression model is better.

\section{Coefficient of Determination (R2) Tabel 5: Coefficient of Determination}

\begin{tabular}{|r|r|r|r|}
\multicolumn{4}{|c|}{ Model Summary } \\
\hline & & $\begin{array}{c}\text { Cox \& } \\
\text { Snell R } \\
\text { Step }\end{array}$ & $\begin{array}{r}\text { Nagelker } \\
\text { likelihood }\end{array}$ \\
\hline 1 & $239.804^{\mathrm{a}}$ & .231 & .340 \\
\hline
\end{tabular}

a. Estimation terminated at iteration number 5 because parameter estimates changed by less than .001 .

Based on Table 5, the Nagelkerke $\mathrm{R}$ Square value is 0.340 . This shows that the variability of the dependent variable can be explained by the independent variable is $34 \%$ while the remaining $66 \%$ is explained by the variability of other variables outside the research model.

\section{Partial Test}

Tabel 6: Variables in the Equation

\begin{tabular}{|cccccc|}
\hline & B & S.E. & Wald & df & Sig. \\
OA & -1.567 & .332 & 22.347 & 1 & .000 \\
KAP & -2.002 & .414 & 23.336 & 1 & .000 \\
FD & -.320 & .191 & 2.805 & 1 & .094 \\
Const & .794 & .332 & 5.716 & 1 & .017 \\
\hline
\end{tabular}

Based on table 6 it can be seen that:

a. The effect of audit opinion on auditor switching. 
H1: Suspected audit opinion has an effect on auditor switching.

The results of the audit opinion show that Wald's value, with a significance value of 0,000 (less than 0.05 ), with a coefficient of 1.567 then $\mathrm{H} 1$ is rejected. The results of statistical calculations show that partially audit opinion variables negatively affect auditor switching.

b. Effect of KAP size on auditor switching.

$\mathrm{H} 2$ : KAP size is suspected to have an effect on auditor switching.

KAP size showed that the Wald value, with a significance value of 0,000 (less than 0.05), with a coefficient of -2.002 then $\mathrm{H} 2$ failed to reject. The results of statistical calculations show that partially the KAP Size has a negative effect on auditor switching.

c. The effect of financial distress on auditor switching.

H3: Allegedly Financial Distress has an effect on auditor switching. The results of a study of Financial Distress show that Wald's value, with a significance value of 0.094 (greater than 0.05), with a coefficient of -0.320 then $\mathrm{H} 4$ is rejected. The statistical calculation results show that partially the Financial Distress variable has no effect on auditor switching.

\section{Logistic Regression}

The logistic regression analysis model can be transformed in the equation model as follows

SWITCH $=0.794-1.567 \mathrm{OA}-$ 2.002KAP - 0.320FD + e
From the regression equation above it can be explained that:

a. A constant of 0.794 means that if the coefficient of the independent variable is considered constant, then the probability of a company conducting auditor switching will increase by 0.794 or $79.4 \%$.

b. Audit opinion coefficient variable of -1.567 means an increase of one unit in the audit opinion will reduce the company doing auditor switching by 1.567 or $157 \%$.

c. Variable KAP variable coefficient of -2,002 means an increase of one unit in the KAP size will decrease the company doing auditor switching by 2,002 or $200 \%$.

d. The coefficient of financial distress variable of -0.320 means an increase of one unit in financial distress will reduce the company doing auditor switching by 0.320 or $32 \%$.

e. Epsilon (error term) or $\mathcal{E}$ means are other factors that affect auditor switching besides audit opinion, KAP size \& financial distress.

\subsection{Discussion}

Partial audit opinion has a significant negative effect on auditor switching This result is indicated by a regression coefficient of -1.567 with a significance level of 0.00 . The results of this study can be explained that the opinion given by the auditor has a negative and significant effect on the change of auditors because the published opinion is based on an agreement between the auditor and the client, so the auditor's opinion is in accordance with the client's request, in addition, in the sample companies, on average the company 
has obtained an unqualified opinion, where if the company has received that opinion, the possibility of auditor switching will decrease or not even do auditor switching because they have already obtained the opinion they want. So, the audit opinion has less influence to do auditor switching.

KAP size partially has a significant negative effect on auditor switching. These results are indicated by a regression coefficient of -2.002 with a significance level of 0.00 . This can be explained because the company will look for a KAP with high credibility to increase the credibility of the financial statements in the eyes of the users of the financial statements. When a company has used the services of Big Four, as much as possible the company will maintain to continue to use KAP services, including Big Four. Therefore, the larger size of the KAP used in the previous year, the less likely the company to do auditor switching.

Financial Distress partially has no significant effect on auditor switching. These results are indicated by a regression coefficient of -0.320 with a significance level of 0.094 . This can be caused by the company being unable to bear the high startup costs if the company changes its auditor due to the company's unstable condition. In addition, the company does not want to incur costs that should not have been incurred, for example, the new auditor assigned to the client company, first thing what needs to be done is to understand the client's work environment and determine audit risk. For auditors who do not understand this situation at all, the auditor will need a higher start-up fee, which in turn can increase audit fees. In addition, auditors who carry out their duties in the early years have a high likelihood of error (Pratitis, 2012: 28).

\section{CONCLUSION}

The conclusions can be drawn from this study, namely:

a. Audit opinion has an effect on auditor switching. This is allegedly because most sample companies have been given an unqualified opinion so that the possibility of auditor switching decreases.

b. The KAP size partially has an effect on auditor switching. This is because companies that already use big four KAP's as their auditors will not replace their KAP's because the reputation of big four KAPs is considered better than non big four KAPs.

c. Financial Distress partially has no effect on auditor switching. This is allegedly because the company will not be able to bear the greater costs for the replacement of public accounting firms in conditions where the company is experiencing an unstable financial condition.

d. Coefficient of determination shows the Nagelkerke R Square value of 0.340 . This shows that the variability of the dependent variable can be explained by the independent variable is $34 \%$ the remaining $66 \%$ is explained by the variability of other variables 
outside the research model.

\section{REFERENCES}

Januarti. (2011). Analisis FaktorFaktor yang Mempengaruhi Pergantian Kantor Akuntan Publik pada Perusahaan Manufaktur di Indonesia. Skripsi. Fakultas Ekonomi Universitas Dipenogoro, Semarang.

Giri, Efraim Ferdinan. (2010). Pengaruh Tenur Kantor Akuntan Publik (KAP) dan Reputasi KAP terhadap Kualitas Audit: Kasus Rotasi Wajib Auditor di Indonesia. Jurnal Universitas Jenderal Soedirman, Purwokerto.

Pasaribu. (2017). Pengaruh mekanisme corporate governance terhadap undepricing (Studi pada perusahaan yang melakukan Initial public offering di BEI periode 2010- 2014). UG Jurnal, 11(3)

Faradila Yuka , M. Rizal Yahya, (2016). Pengaruh opini audit, financial distress, dan pertumbuhan perusahaan klien terhadap auditor switching (studi pada perusahaan Manufaktur yang terdaftar di Bursa Efek Indonesia tahun 2010-2014). Jurnal Ilmiah Mahasiswa Ekonomi Akuntansi (JIMEKA) ,1(1), 81-100

Sinarwati, Ni Kadek. (2010). Mengapa Perusahaan Manufaktur yang Terdaftar di BEI Melakukan Pergantian Kantor Akuntan Publik?. Jurnal Universitas Jenderal Soedirman Purwokerto.
Arens et. al. (2012). "Auditing and Assurance Services: An Intregrated Approach". Fourteen Edition : Prentice Hall.

Wolk, H. I, and Michael G. Tearney, (2018). Accounting Theory: A Conceptual and Institusional Approach 4 th ed. Ohio, SouthWestern College Publishing

Lesmana, Kevin \& Ratnawati Kurnia. (2016). Analisis Pengaruh Pergantian Manajemn, Opini Audit Tahun Sebelumnya, Financial Distress, Ukuran KAP, dan Ukuran Perusahaan Klien Terhadap Voluntary Auditor Switching. (Studi Pada Perusahaan Manufaktur di BEI Periode 2012-2014. Jurnal Ultima Accounting, 8(1)

Utami, Suci Rismanda. (2013). Pengaruh Opini Audit, Ukuran KAP, Ukuran Perusahaan Klien, dan Financial Distress Terhadap Auditor Switching. (Studi Empiris pada Perusahaan Manufaktur yang Terdaftar di Bursa Efek Indonesia tahun 2008-2012)". Skripsi. Fakultas Ekonomi dan Bisnis Universitas Hasanuddin, Makassar.

Haruman, Dimas Putra. (2016). Analisis Faktor-Faktor yang Mempengaruhi Auditor Switching di Indonesia (Studi Empiris pada Perusahaan Manufaktur yang Terdaftar di Bursa Efek Indonesia Tahun 2010-2014). Skripsi. Fakultas Ekonomi dan Ilmu Sosial, Universitas Bakrie, Jakarta.

Pratitis, Yanwar. (2012). Auditor Switching: Analisis Berdasar 
EAJ (Economics and Accounting Journal) - Vol. 3, No. 1, Jan 2020 - Natalia \& Purnomo

Ukuran KAP, Ukuran Klien, dan

Analysis Journal, 1(1)

Financial Distress. Acccounting 